\title{
ESCRITURA DE LA NOVELA Y DEL CINEMA COMO CRÍTICA DE LA COMUNICACIÓN GLOBAL ${ }^{1}$
}

\author{
Augusto PONZIO \\ Universidad de Bari (Italia) \\ augustoponzio@libero.it \\ http://www.augustoponzio.com/
}

Resumen: Este artículo examina la contribución que nosotros podemos extraer de la concepción de la escritura literaria y cinematográfica, expresada por autores como Bajtín, Eisenstein, Pasolini y Deleuze para la construcción de una crítica a la ideología dominante.

Abstract: This essay examines the contributions made by the conception of literary and cinematographic writing of Bakhtin, Ejzenstein, Pasolini, and Deleuze to our critique of dominant ideology.

Palabras clave: Novela. Cine. Comunicación global. Ideología. Discurso indirecto libre.

\footnotetext{
${ }^{1}$ Este artículo reelabora, profundiza y desarrolla algunas consideraciones expresadas en dos de mis libros (Ponzio, 1995 y 1998), que aparecen en español con traducción de Mercedes Arriaga Flórez, y en un libro más reciente (Ponzio, 2003).
} 
Key Words: Novel. Cinema. Global communication. Ideology. Free indirect discourse.

\section{EL DISCURSO INDIRECTO LIBRE}

La escritura literaria, sobre todo la novela, y la escritura del cine contribuyen a la «subversión no sospechada» (E. Jabès) de la ideología oficial de la comunicación global de nuestra época.

Hay un «lugar teórico» donde tres autores (Bajtín, Pasolini y Deleuze) se encuentran - los tres autores, los «otros» de la cultura oficial, de la cultura del Estado, y aislados-. Bajtín, obligado al silencio por el socialismo real, después de las publicaciones suyas y de su círculo de los años 20 y que murió en 1975; Pasolini, matado en el mismo año y autor de una lúcida denuncia de la tolerancia y de la ideología de la «producción creadora del bienestar» funcionales al nuevo poder económico que se iba afirmándose en Italia; Deleuze, desaparecido quitándose la vida en 1995 y que en los años 70 continuó la denuncia de Pasolini y participó contra la «represión en Italia», causando la indisposición del entonces Ministro del Interior. El «lugar teórico» del encuentro es la reflexión sobre el discurso indirecto libre, estudiado poco por la lingüística, la estilística y la crítica; y que es objeto de atención por parte de Pasolini (1972) y de Deleuze, y de los estudios de Bajtín sobre la literatura. El discurso indirecto libre en la novela y paralelamente la «subjetiva indirecta libre» (P. P. Pasolini) en el cine puede crear anticuerpos que contrasten la «peste del lenguaje» (I. Calvino), que, con la reducción de la lengua a «lengua comunicativa» (Pasolini), contagia también a las imágenes y a la vida de las personas.

Este artículo examina la contribución que nosotros podemos traer de la concepción de la escritura literaria y cinematográfica expresada por autores como Bajtín, Eisenstein, Pasolini y Deleuze para la construcción de una crítica a la ideología dominante.

\section{GLOBALIZACIÓN Y ESCRITURA LITERARIA}

Con la expansión del capitalismo, el mercado ha realizado su tendencia a ser mercado mundial y con él también la comunicación tiene difusión mundial. Esto significa que todos los programas de la comunicación están comprendidos en un único gran proyecto que se identifica con el plan de desa- 
rrollo del capital. Este plan tiene sus raíces en la misma realidad del capital, de tal modo que la ideología del capital es su lógica. Lo que caracteriza la comunicación en la fase actual de la reproducción social es, por lo tanto, la defensa de la Identidad, de la reproducción del Mismo, de la Totalidad, de la Realidad, del «Ser» (cf. Lévinas, 1961 y1974; Ponzio, 2003a). En un universo donde todo comunica consigo mismo, donde lo que se comunica se refiere a la Identidad y a su reproducción, la comunicación se va vaciando.

Si es verdad que entre mensaje y medio no existe diferencia, la reducción del significado al significante no comporta, en ese caso, ninguna superioridad de este último respecto al significado establecido, ninguna posibilidad de dar lugar a significados diferentes respecto al mismo: el significante está al servicio de su significado, de su función, aunque no exista otro significado que el significante mismo, otra función comunicativa que la comunicación misma. Por lo tanto, como dice Pasolini (1976), la lengua es reducida a «lengua comunicativa». La reducción del significado al significante indica solamente que el intercambio igual entre ambos se ha convertido en intercambio igual entre significante y significante, en el que no sobra nada, no hay suplemento. Lo que se realiza siguiendo un proceso de identificación, en el que, incluso la excedencia del signo en su intérprete, se concluye con un retorno a sí mismo, con la negación de cualquier otro, y con la convalidación de su identidad. Al monologismo de la comunicación se corresponde, a nivel verbal, la tendencia hacia el monolingüismo, tanto en su forma externa, como imperialismo lingüístico, como en su forma interna, como estandarización de la lengua, como pérdida efectiva de la diversificación de sus lenguajes internos, como pérdida de expresividad en favor de la comunicación fácil, eficaz y rápida (cf. Ponzio, 1974 y 1992). El igualamiento expresivo afecta también a lenguas diferentes, que, a pesar de su diversidad, se utilizan simplemente como si fueran medios distintos para expresar lo mismo.

Pero la homologación no afecta solamente al lenguaje verbal. Afecta a cualquier comportamiento en tanto que signo. A un mercado universal se corresponde una comunicación universal que expresa las mismas necesidades, las mismas exigencias, los mismos deseos, los mismos imaginarios. Al «cierre del universo de discurso» se corresponde el cierre del universo comunicativo en general, del universo semiótico humano.

Como escribe Italo Calvino, parece que una epidemia de peste ha contagiado a la humanidad, una peste del lenguaje que se manifiesta como automatismo que tiende a nivelar la expresión a fórmulas más genéricas, abstractas y a disolver los significantes; pero la peste no contagia solamente las 
imágenes o el lenguaje: contagia también la vida de las personas, uniforma todas las historias informes, casuales, confusas (cf. Calvino, 1988).

En una comunicación unitaria, compacta, monológica, carente de oposición efectiva, parece que la lucha y también el diálogo, la dialéctica entre las ideologías, por lo menos a grandes líneas, han sido sustituidas por la monotonía de un solo punto de vista dominante que impone el silencio, que obliga a hablar según su lógica, según su «ideo-lógica» (cf. Ponzio, 1998 y 2004; Ponzio y Petrilli, 2002 y 2003; Petrilli y Calefato, 2003). Esto hace que se haya creado la impresión de que se asiste al fin de las grandes ideologías. En realidad, depende del hecho de que la ideología dominante y su ars rethorica (la crítica de las falacias retóricas en Petrus Hispanus, 1230, siempre es válida) puede imponer y reproducirse a sí misma automática y silenciosamente, confiriendo a sus signos el carácter de cosas y relaciones naturales e inmodificables, sin deber pedir escucha, sin agitar banderas, sin necesidad de buscarse un nombre porque no hay nada de lo que deba diferenciarse. Si necesita recurrir a un nombre, todo lo más, la ideología dominante utiliza un genérico y gastado término —una especie de «palabra-comodín», un passepartout: «Democracia» (cf. Morris, 1948; Ponzio, 1994)—.

No sólo a nivel de comunicación normal, sino también a nivel de reflexión teórica, se ha llegado a identificar democracia con capitalismo y a contraponer democracia a comunismo. Este gran equívoco, según el cual, incluso los seguidores de Marx, confunden formas económicas y formas políticas, no es simplemente teórico: en él se expresa la identificación entre ideología y realidad del capital, llegando a sostener que no puede existir otra democracia que la del capitalismo. De hecho, el comunismo es una forma económica cuyo punto de comparación y de contraposición puede ser el capitalismo, también forma económica; la democracia, en cambio, es una forma política. Y como la forma económica capitalista se presenta en sociedad con sistemas políticos diferentes - sistemas republicanos y monárquicos, democracias parlamentarias o dictaduras totalitarias, sistemas con uno o más partidos-, también la forma política de la economía comunista puede adoptar sistemas políticos diferentes (lo que confirma la inexistencia de una relación de determinación mecánica entre «base» y «superestructura»): pluralismo político o sistema monopartítico, democracia o dictadura, o incluso presentarse como sistema totalitario, como sistema comunista-fascista (cf. Schaff, 1993a y 1998).

La asimilación gradual también de los «países socialistas», en el mercado mundial, ha comportado, o el debilitamiento hasta anularse de su oposición a la ideo-lógica dominante, o su atrincheramiento en defensa de una forma 
económica de socialismo que, llevándose a cabo preferentemente en sociedades con un bajo nivel de desarrollo de las fuerzas productivas, con la fuerza y la violencia, y también porque obstaculizada en gran medida por los países capitalistas, ha sido encauzada desde el principio hacia formas políticas totalitarias, antidemocráticas. También en el segundo caso, contra la ideología capitalista no se ha producido ninguna real oposición ideológica, es más, mientras el capitalismo ha podido exhibir orientaciones políticas, liberales y democráticas, en cambio, en defensa de una forma económica alternativa al capital, la ideología socialista se ha concretado en formas políticas atrasadas y primitivas, las mismas a las que los países capitalistas acuden en casos extremos de defensa, para salvar a toda costa los intereses del capital (cf. Schaff, 1993b).

La comunicación de la globalización, como comunicación de la comunicación, impone el silencio. El silencio es entonces el lugar de la Identidad, de la Totalidad, de la Monología, de la Univocidad, del Sistema lingüístico, del Intercambio igual, del Poder, de la Homologación de las necesidades y de los deseos. El silencio es el lugar del Significado, de lo Dicho (Lévinas, 1961; Ponzio, 1993), en el sentido de Lévinas, de la Ley, del «Orden del discurso» (Foucault).

A su vez, el callar es el lugar de la Alteridad, de la Plurivocidad, de la Plurilogía, del Diálogo, del Escuchar como espacio interpersonal, en donde «yo escucho» significa también «escúchame» (Barthes); es el lugar del Vocativo, de la Significación del mismo Decir; es el lugar en el que la iconicidad del Rostro del otro, con su sentido para sí, con su alteridad absoluta, pone en crisis el convencionalismo simbólico y la obligación indicial de los signos y pregunta sin dirigirse, es más, impone una responsabilidad absoluta con respecto a sí, una responsabilidad incondicional, sin disculpas (cf. Bajtín, 1920-24; Ponzio, 1996). El callar no está al servicio de la palabra, no es funcional y productivo con respecto al Significado. El silencio está al servicio de la palabra, es funcional y productivo con respecto al Significado. El callar tiene, por el contrario, las características que Blanchot atribuye a la «otra noche», la que no sirve a la productividad del día.

El callar no es solamente mutismo. El callar no ha salido del lenguaje, sino que es también hablar indirecto, palabra distanciada, palabra irónica, parodia, alegoría: palabra de la escritura literaria (cf. Petrilli y Ponzio, 2000).

Como Kierkegaard, teórico de la palabra indirecta, observa en la «Postilla conclusiva no científica» (Kierkegaard, 1995), la palabra directa, objetiva no se preocupa de la alteridad, de la palabra otra con respecto a sí misma, no se 
preocupa de la alteridad del sujeto que se hace la ilusión de objetivarse en la palabra directa, de identificarse con la misma; es decir, no se preocupa de su alteridad singular, con respecto a sí mismo, como individuo con un género, con un papel, con una posición social. La palabra directa, objetiva, no se preocupa de la alteridad del interlocutor si no es para adelantarla, englobarla, asimilarla; esta palabra atiende sólo a sí misma y por eso, como dice Kierkegaard, no constituye propiamente comunicación ninguna, o bien, podemos decir, es sólo comunicación del silencio (cf. Ponzio, 1995: 35-53).

El callar, como hablar indirecto, puede consistir en «la acción de desvío ejercida sobre la lengua» que Barthes considera propia de la escritura literaria (Barthes, 1978). «Escritor», dice Bajtín en los «Apuntes» del 1970-71, es el que sabe trabajar sobre la lengua permaneciendo fuera, es el que posee el don del hablar indirecto. El escritor, continúa Bajtín, viste el hábito del callar. Pero este callar, sigue diciendo Bajtín, puede asumir diferentes formas de expresión, diferentes formas de sonrisa inducida (ironía), de alegoría, etc. (cf. Ponzio, 1998 y 2003; Romera et alii, 1995). La escritura literaria permite hacer lo que Perseo, el «héroe ligero» que I. Calvino (1988) elogiaba, hace en el mito cuando vence a la Medusa. Perseo vence al monstruo, cuya mirada petrifica, mirándolo no directamente y tampoco evitando mirarlo y dirigiendo su mirada a otra parte, sino mirándolo indirectamente, reflejado, como dice el mito, en el escudo. Paralelamente, la escritura puede librarse de la petrificación de la realidad mirando las cosas, pero de forma indirecta. Por eso, Calvino puede escribir que la literatura (y quizás no sólo la literatura) puede crear anticuerpos que contrasten la expansión de la peste del lenguaje, esta epidemia del lenguaje que podemos atribuir a la política, a la ideología, a la uniformidad burocrática, a la homologación de los medios de comunicación, a la difusión de la cultura media en las escuelas.

Las posibilidades de esta práctica del callar de la escritura literaria con respecto al silencio como forma dominante de la comunicación moderna las analiza Pasolini en un texto titulado Il romanzo delle stragi. Este escrito empieza rompiendo el silencio con un «YO SÉ». Y prosigue: «Yo sé los nombres de los responsables de los golpes de Estado y de los atentados en Italia y de la serie de golpes realizados como sistema de protección del poder». Como escritor, como novelista, Pasolini sabe los nombres de los responsables de los golpes de Estado y de los atentados en Italia, pero no posee ni las pruebas ni los indicios, a diferencia de los políticos y de todos los que, por su relación con el poder, pueden tener pruebas o, por lo menos, indicios. Se trata de un saber que le proviene del hecho de ser un escritor, un inventor de historias, un novelista que intenta seguir todo lo que sucede, conocer todo lo 
que no se sabe o se calla; que pone en relación hechos extraños unos a otros, que coloca las piezas desordenadas y fragmentarias de un entero cuadro político coherente, que restablece la lógica en donde parecían reinar la arbitrariedad, la locura, el misterio (cf. Pasolini, 1990: 89-90). Se trata de un saber sin pruebas y sin indicios que, como tal, puede denunciar, acusar, pero sin poder; que puede denunciar y acusar porque no está comprometido en el ejercicio del poder, porque está fuera de la política, pero, precisamente por esto, no es el Saber de las pruebas y de los indicios y no tiene poder (cf. también la última novela de Pasolini, Petrolio, 1992).

Y aún así, sin ningún poder, la palabra indirecta de la literatura, esta forma de callar, alusiva, paródica, irónica, esta forma de reír, es la que afirma hoy con mayor fuerza los derechos de la alteridad contra la homologación de la identidad, de la comunicación del silencio (cf. Ponzio, 1994 y 2001).

Bajtín (1920-24) ha tomado como punto de partida la exigencia de una fenomenología de la actividad responsable, de una filosofía de toma de posición, de la elección sin disculpas, de la no indiferencia, cuyos momentos son yo para mí, el otro para sí, el otro para mí y yo para el otro. Bajtín escoge describir este mundo de la acción sin disculpas a través de la visión estética, a través del callar del arte, sobre todo de la literatura, porque en la concreción y penetración de su tono emotivamente volitivo se encuentra más cercana, que todos los mundos culturalmente abstractos (en su aislamiento), al mundo uno y único de una toma de posición (cf. Ibidem). Para describir la unicidad de una toma de posición sin disculpas hace falta salir del mundo de la identidad y dirigirse al de la alteridad. La actividad estética, por principio, se dirige a la escucha de la alteridad. El mundo en relación a mí, dice Bajtín (cf. Ibidem), por principio no puede entrar en la arquitectónica estética, como veremos detalladamente más adelante, contemplar estéticamente significa colocar un objeto en el plano de valor de otro (Ibidem). La investigación de toda su vida está dedicada al estudio de la transfiguración estética, de cómo callar en función de una responsable escucha de la alteridad.

\section{EXOTOPIA Y DISCURSO INDIRECTO LIBRE EN LA NOVELA Y EN EL CINE}

En un fragmento de los Apuntes de 1970-71 Bajtín afirma la peculiaridad del diálogo polifónico en cuanto diálogo literario. La literatura —en este caso la novela en su forma especial de novela polifónica- permite realizar con el lenguaje lo que fuera de la literatura no se puede realizar, por el carácter fi- 
nito, completo del diálogo extraliterario. El diálogo polifónico es un diálogo sobre los últimos problemas. Los personajes del diálogo polifónico no son sujetos psicológicos, sujetos reales: son, en cambio, personalidades incompletas, que no tienen igual en la realidad extraliteraria. Los mismos quedan fuera del intercambio dialógico real, de la economía de la comunicación ordinaria: su palabra presenta una excedencia desinteresada, con respecto al intercambio comunicativo como se realiza fuera del espacio literario, fuera de la experimentación posible en el género novela. La escritura literaria se diferencia de la escritura que está al servicio de fines científicos, propagandísticos, políticos, informativos, etc., por el hecho de que escapa del horizonte de la contemporaneidad, queda libre de la división de papeles de la vida real, no se somete a la regla del discurso funcional y productivo, por el cual el que habla se identifica con el yo del discurso y lo convierte en «palabra propia», de la cual él es responsable, responde en primera persona.

Dicha diferencia puede apreciarse entre Dostoievski escritor - que como tal logra representar el diálogo polifónico, incomponible e infinito, situado (o mejor «extralocalizado») en el «tiempo grande de la literatura»- y Dostoievski periodista que, como tal permanece en la frontera de un diálogo terminado, adherente y funcional a los problemas reales y por lo tanto, completamente comprensible y justificable dentro de los límites del contexto cultural de su época.

La exotopia es la condición determinante de la palabra literaria, como lo es la participación en los contenidos y a los valores de la vida social. La obra literaria asume formas diferentes según se organice la dialéctica entre «estar dentro» $\mathrm{y}$ «estar fuera» de la palabra literaria, que comporta siempre una cierta distancia - también donde parece que existe identificación- entre autor y héroe o personaje, como condición para que el contenido reciba forma artística. Resulta, por lo tanto, que la palabra literaria es siempre palabra indirecta, a pesar de que Bajtín caracteriza algunos géneros literarios (el epos, la poesía lírica, por ejemplo) como géneros de la palabra directa. Además por su exotopia, la palabra literaria es siempre dialógica, a pesar de que en relación a los géneros más dialógicos (la novela, y especialmente la «novela polifónica») Bajtín considera algunos géneros y algunas de sus variantes como monológicos (la misma caracterización de la novela de Tolstoi como «monológica» evidentemente lo es con respecto a la novela polifónica de Dostoievski).

Si algunos géneros literarios se caracterizan como relativamente serios, la palabra literaria, precisamente por su exotopia, es siempre palabra irónica, palabra que toma distancia, que no se identifica totalmente con su propio 
contenido. Incluso en donde, como en la autobiografía, el autor se identifica con el personaje, la literatura del texto depende de un determinado grado de distanciamiento entre autor y personaje, que hace que el personaje, por decirlo así, no se tome del todo en serio, que su visión del mundo se presente como relativa y superada desde un punto de vista externo: esto lo convierte en personaje incompleto, haciéndolo salir de los límites del mundo que hacen que su palabra sea completa y terminada. La escritura literaria se coloca siempre más o menos fuera del discurso funcional y productivo. Al colocarse fuera de la vida, la escritura literaria tiene algo que ver con la muerte y mira siempre las cosas humanas desde el «umbral extremo» y, por lo tanto, con cierta ironía, con una actitud serio-cómica, más o menos acentuada según los géneros literarios y sus variantes.

La exotopia comporta la alteridad de la escritura, que no es la alteridad complementaria para el cumplimiento de la conciencia individual, para su constitución como totalidad; la misma no es la alteridad necesaria a la constitución de la identidad; no es la alteridad funcional a la esfera del Mismo. En este sentido la dialogía de la escritura literaria se diferencia de la escritura que se dirige a la realización de un fin determinado, científico, ético, político, pedagógico, etc.

La exotopia, que caracteriza a la escritura literaria y que se realiza de forma diferente según los diferentes géneros, se sirve de las normas lingüísticas que regulan la relación entre la propia palabra y la palabra ajena, pero obteniendo efectos especiales. En la última sección de El marxismo y la filosofía del lenguaje (Voloshinov, 1929), se examina la utilización de las normas lingüísticas del discurso directo, indirecto, y libre indirecto en función de la representación de la palabra ajena dentro de la escritura literaria (cf. también A. Ponzio, «La manipulación de la palabra ajena», en Ponzio, 1995).

En las formas de representación del discurso ajeno, previstas por la lengua, se manifiestan las posibilidades que dicha lengua ofrece de distanciamiento entre la propia palabra y la palabra ajena. Dichas posibilidades, a su vez, se corresponden con determinadas condiciones histórico-sociales, con la fuerza de la ideología dominante, con la hegemonía de una cultura (relativamente) unidimensional o con su desintegración en favor de una visión plurívoca de la realidad; se corresponden con la capacidad de persistencia de un determinado sistema social ante el surgir de contradicciones sociales, y por lo tanto ante puntos de vista alternativos que se expresan verbalmente. La dialéctica entre ideología oficial e ideología no oficial la analiza directamente Voloshinov (1927). 
Condiciones sociales especiales han conducido al dominio de ciertas formas de orientación con respecto al discurso ajeno, que se han convertido en «gramaticales» en una lengua dada, se han asumido como modelos sintácticos de esa lengua y determinan la percepción y la representación de la palabra ajena por parte de los hablantes de dicha lengua. Así, el discurso libre indirecto no es simplemente un modelo sintáctico; expresa también una orientación ideológica especial, una forma particular de conciencia del intercambio lingüístico; indica condiciones socio-económicas especiales y realiza una comparación entre lenguajes, estilos e ideologías diferentes, hace relativos los puntos de vista, desacraliza la palabra monológica. Encontramos consideraciones parecidas en lo que observa Pasolini a propósito del discurso libre indirecto en Dante y Ariosto. El discurso libre indirecto es generalmente, como dice Pasolini, índice de una ideología, implica una conciencia sociológica del autor, y coloca cara a cara lenguajes, estilos e ideologías diferentes, convierte en relativos los punto de vista, desarma la palabra monológica. Que en Ariosto exista el discurso libre indirecto, dice Pasolini, no es un simple título de mérito respecto a La Fontaine, pero es un hecho históricamente significativo. Se ve que ha existido un momento en la sociedad italiana con características que se han repetido de forma más o menos vasta y estable un siglo y medio después en Francia, etc. En el lenguaje de Ariosto la lengua feudal y la lengua burguesa, la lengua de las armas y la lengua del comercio y de los bancos forman una continuidad, no tiene solución de continuidad. El discurso de Ariosto —el juego de la ironía ariostesca- se realiza entre el lenguaje alto y el lenguaje medio. Tampoco es casual el uso del estilo libre indirecto en Dante: su presencia en la Divina Comedia expresa las contradicciones lingüístico-ideológicas propias de la sociedad comunal («Intervento sul discorso libero indiretto», en Pasolini, 1972: 89-90).

Comprendemos ahora la importancia que Bajtín atribuye al discurso libre indirecto en la dialéctica entre monología y polilogía. Lo que Pasolini observa a propósito de la presencia del estilo libre indirecto en Dante o en Ariosto puede ser particularmente significativo para el papel que le asigna Bajtín en la dialéctica entre monología y polilogía.

Resulta claro el papel de los modelos del discurso reproducido y de sus variantes («discurso diseminado», «discurso directo retórico», «discurso directo substituido», etc.) en la escritura literaria, visto que la relación formacontenido puede explicarse como relación entre la propia palabra y la palabra ajena, con grados diferentes de exotopia, según los géneros literarios y su historia. Al problema del discurso reproducido Bajtín vuelve en «Il problema del testo» (en Bajtín, 1979; cf. también Voloshinov, 1929): las palabras están 
distribuidas en diferentes planos a diferentes distancias del plano de la palabra del autor: la palabra usada entre comillas, es decir, sentida y usada como de otro y esa misma palabra sin comillas; graduaciones infinitas de niveles de extrañamiento (o de apropiación) de las palabras, sus diferentes distancias del hablante.

En la exotopia de la palabra literaria se expresa la distancia respecto al propio ser que es constitutiva de la conciencia humana. La conciencia y la autoconciencia comportan, dice Bajtín, una alteridad que se expresa en la palabra como realización de la conciencia y de la autoconciencia.

«El escritor, señala Bajtín en las notas del 1970-71, no tiene un estilo propio, sino que pone en escena los estilos y los discursos, sin identificarse con ninguno de ellos. Los sujetos que el escritor hace hablar tienen un propio estilo y una propia situación; el escritor en cambio está falto de estilo y de situación»; el escritor habla con reserva, asume la prosa, estiliza, y parodia.

En las prácticas significantes que Bajtín contrapone a las de tipo monológico y que se pueden llamar de tipo «polilógico» (cf. también J. Kristeva, 1977) la palabra se convierte en "palabra a dos voces», asume una doble dirección, hacia el objeto del discurso y hacia la palabra ajena. Aquí ya no nos encontramos con la palabra únicamente objetivante, ni con la palabra objetivada unívoca, sino con un tipo de palabra que tiene en cuenta la palabra ajena. En este caso, las relaciones dialógicas no se realizan solamente entre enunciaciones, sino que se insinúan en la misma enunciación, incluso en un sólo término.

No sólo en la lengua, en los modelos que ofrece para reproducir el discurso ajeno, se pueden detectar determinados modelos de percepción y de manipulación del discurso ajeno. También los géneros literarios implican diferentes formas ante la palabra ajena, y se renuevan también según el modo en que se siente el discurso de los demás. Bajtín considera que precisamente estas formas estriban la diferencia entre «géneros literarios serios» y «géneros literarios paródicos», entre epos y novela, entre «novela monológica» $\mathrm{y}$ «novela polifónica». Así, en la novela, la lengua de la novela no puede colocarse sobre un sólo plano y desarrollarse en una sola línea. Es un sistema de planos que se integran. Toda novela es, en mayor o menor medida, un sistema dialogizado de las imágenes, de los estilos de las conciencias concretas e indivisibles de la lengua. La lengua de la novela no sólo representa, sino que sirve ella misma como objeto de representación. Por esto, la palabra de la novela es siempre autocrítica. Es en esto que la novela se diferencia de los demás géneros literarios directos: del poema épico, de la lí- 
rica, del drama, en sentido estricto (cf. «De la preistoria della parola romanzesca», en Bajtín 1975).

La misma interrelación entre géneros literarios, su recíproca influencia puede leerse como un aspecto de la manipulación de la palabra ajena. La «palabra ajena» respecto al género novela, la de los otros géneros, es decir, sus medios de representación y de expresión, entrando en la novela, y convirtiéndose en objeto de representación, asumen acentos diferentes. Cuando la novela entra en la gran literatura y se convierte en el género literario dominante, la relatividad que caracteriza la propia palabra penetra también en los otros géneros: los demás géneros literarios «se novelizan», es decir, adquieren el carácter de la estilización, la técnica de la palabra distanciada, puesta entre «comillas», en algunos casos presentan también el fenómeno de la estilización paródica (cf. Ponzio, 1998 y 2003b).

El discurso indirecto libre es un espía y también una práctica de la crítica del Sujeto y de todo lo que está ligado con la ideología occidental (y no es una causalidad que hoy la novela polifónica se desarrolla sobre todo en el Sur del mundo, en Affrica, en América Latina: veáse Krysinski, 2003): la identidad, la Diferencia, la Pertinencia, el Monologismo, el Ser, la Objetividad, la Narración, la Memoria, la Historia, la Verdad, el Significado, la Razón, el Poder...

Según Pasolini, lo esencial de la imagen fotográfica en el cine contemporáneo, como «cine de escritura», es el no ser ni objetiva (visión exterior al personaje) correspondiente al discurso indirecto, ni subjetiva (visión del personaje) correspondiente al discurso directo, pero semi-objetiva. En ésa, paralelamente al discurso indirecto libre, los dos puntos de vista están juntos, no fundidos, sino dialógicamente. Este desdoblamiento es lo que Pasolini llama «subjetiva libre indirecta».

Deleuze considera la idea del discurso indirecto libre la forma esencial de la nueva novela y del nuevo cine, y examina en las películas de Pasolini el mismo papel de la «subjetiva libre indirecta» y el efecto de contaminación. Deleuze, en el trabajo dedicado al cine (Cinema 1 y Cinema 2 ), sitúa el indirecto libre y la «subjetiva indirecta libre» de Pasolini en un discurso más amplio de la misma reflexión sobre el cine.

\section{POLIFONÍA DRAMATÚRGICA DEL CINE}

Un concepto que me parece fundamental, en la actividad teórica y creativa de Eisenstein, es el de la «polifonía dramatúrgica de los medios de acción 
cinematográfica» (Eisenstein, 1946). «Polifonía»: el término hace referencia a Bajtín. La orquesta, dice Eisenstein, representa el prototipo de la manera correcta de actuar para poder utilizar cualquier sector expresivo al máximo de sus posibilidades al mismo tiempo que se coloca en el conjunto general. Polifonía como heterogeneidad de medios expresivos, cuyas «voces» se encuentran recíprocamente respetadas y diferenciadas, aunque coordinadas a través de una experta «orquestación».

La función dramatúrgica de los medios expresivos conlleva, por otra parte, que la polifonía, en un momento dado del desarrollo del discurso fílmico, es capaz de conseguir que un determinado elemento expresivo sobresalga al máximo de sus posibilidades, de modo tal que alcance más pertinencia que los demás, y pueda funcionar como significado principal de lo que en ese momento se desea expresar. La polifonía se concibe, por lo tanto, como utilización de los medios expresivos en función del efecto dramatúrgico.

Así como en Bajtín el carácter polilógico de una obra literaria no viene dado por la presencia de la forma del diálogo, por el subseguirse de situaciones en las que los personajes dialogan entre ellos, no depende de la cantidad de respuestas y de partes que se presentan en la obra, sino que se refiere, en cambio, a la posibilidad que tiene la obra de ser un discurso con varias voces, con diferentes puntos de vista, paralelamente en Eisenstein, la polifonía dramatúrgica no indica el hecho de que se utilicen, todos a la vez y al mismo tiempo, diferentes medios expresivos, sino que en el conjunto de la obra fílmica se alternen según las necesidades expresivas.

Este alternarse no es neutralización de un medio expresivo para favorecer otros. La orquestación, en cambio, significa que un medio expresivo es capaz de sobresalir, precisamente a través de un correcto y pertinente uso de los demás. Eisenstein observa cómo en la orquestación no existe un continuo estruendo de todos, sino una recíproca acción concordada que no impide que cada elemento aparezca en el momento oportuno con todo su esplendor, exactamente de la misma manera, la entera construcción de la obra cinematográfica no se realiza sobre la base de una recíproca obstrucción de cada uno de los sectores, sino se trata de colocar premeditadamente en primer plano, precisamente esos medios de expresión que en un momento determinado traducen mejor el elemento, que, en una circunstancia dada, conduce más directamente a la completa revelación del contenido, del significado, del tema, de la idea de la obra. 


\section{CINE COMO CRÍTICA DE LA REPRESENTACIÓN: REALISMO DOMINANTE Y REALISMO DEL CUERPO GROTESCO}

«Polifonía dramatúrgica de los medios expresivos»: esta función dramatúrgica, el hecho de que todos los medios expresivos tienen que formar parte de la película como elementos dramatúrgicos, conlleva el rechazo por parte de Eisenstein de la concepción de la imperceptibilidad de cada uno de los componentes de la obra, según el que sea preferible en la película, la música que no se advierta, el trabajo del cámara que no se vea, la presencia del color que no se haga notar.

Para Eisenstein, la imperceptibilidad de algunos elementos expresivos, que no es sin embargo neutralización, es sólo funcional a su máxima manifestación. De hecho, cada sector, cuando se prepara a resplandecer de ahí a pocos minutos como sector guía, tendrá que intentar disimular. Todavía con más meticulosidad, su presencia, tendrá que esconderse en el silencio, disolverse en la imperceptibilidad. Pero ciertamente no con el fin de neutralizarse respecto al resto de los instrumentos: retrocederá para avanzar mejor, aprovechando el contraste con la imperceptibilidad precedente para aumentar el efecto de su aparición.

Nos encontramos aquí con una vuelta de la dialéctica entre imperceptibilidad y percepción - percepción fuerte y renovada hasta llegar a un «extrañamiento»— que en ciertas tendencias del formalismo ruso se reduce a la falsa contraposición entre «lenguaje práctico» $\mathrm{u}$ «ordinario» $\mathrm{y}$ «lenguaje poético». La imperceptibilidad y la automatización son, para Eisenstein, el efecto de un cierto realismo en el arte, y especialmente en el cine, que desea, en nombre de la fidelidad a los objetos reales, que los medios expresivos sean lo menos visibles posible.

A la concepción de la obra como pasivo reflejo, Eisenstein contrapone la de una obra que tiene que proporcionarnos una imagen dinámica, viva, diferente de cualquier pasiva reproducción. Para Eisenstein, el cine audiovisivo, como expresión artística, empezó cuando el chasquido de la bota quedó separado de la imagen de la bota que chirría y fue unida al rostro del hombre que escucha ese chirrido con ansia. No sólo se rompe así el nexo, pasivo y realista, que une objeto y sonido, sino que además se crea un nuevo nexo, que rompe «el orden de las cosas» y al mismo tiempo responde al tema que, en ese momento, se ha querido expresar. Para Eisenstein es importante la reacción del personaje, independientemente del hecho que sea un héroe o un forajido, con el chirrido, relación que expresa un aspecto que él juzga te- 
máticamente necesario. La obra fílmica y, en general artística, requiere que nos separemos de la «realidad cotidiana» del hecho o «fenómeno en sí», y que se rompa, de esta forma, la inercia del indiferente «orden de las cosas» en función del punto de vista que se desea expresar, estableciendo «un nuevo orden de concatenación y un nuevo sistema de relaciones, con el único fin de conceder a la pasiva realidad del suceso una dinámica y dramática eficacia formativa, capaz de poner de manifiesto una actitud con respecto a ese hecho, y al mismo tiempo, expresar una concepción del mundo».

Lo que estamos diciendo es válido, también, para el uso del color como elemento dramatúrgico y dramático de la obra fílmica. También en este caso hace falta liberarse de la visión realista que sigue fielmente el nexo entre objeto y color. Con el color hace falta realizar la misma separación que en el montaje se realiza entre sonido y objeto, como en el caso del chirrido de la bota que se separa de la imagen de la misma bota, para que pueda convertirse en elemento de expresión. En la función dramatúrgica es donde encuentran motivación y pertinencia, precisamente los instrumentos expresivos que son arbitrarios respecto al realismo del orden de las cosas.

Esta dialéctica de arbitrariedad / motivación permite a Eisenstein el acercamiento del color a la música: afirma que, como la línea de resonancia musical atraviesa las imágenes, de la misma manera podrá también atravesar la línea del color. Este último puede atravesar, como la misma música, momentos de pausa o de censura, una censura cromática, que permite, cuando el momento lo requiera, utilizar todas las posibilidades expresivas del color. La línea del movimiento del color tiene, con respecto a la de las imágenes, la misma independencia que la línea musical, y es igualmente ininterrumpida como esta última, aunque existan momentos de pausa o de censura. Precisamente esta independencia, y la posibilidad de manifestarse o esconderse, concede al medio expresivo seriedad y pertinencia, lo convierte por lo tanto en plenamente motivado en todos y cada uno de sus usos y lo coloca, como parte diferente, en la polifonía total de los medios expresivos.

Por tanto, otro concepto importante para Eisenstein, estrechamente unido al de la polifonía, es el concepto de «separación». Separación del chirrido de la bota, separación del color naranja y del mandarina. Separación como momento de rotura de la mera coexistencia de los elementos de un fenómeno y, por lo tanto, como momento en el que se inicia la superación de los nexos pasivos y realistas. Separar el color del objeto permite, por ejemplo, realizar lo cómico a color, porque lo separa de su contexto normal y le permite cargarse de nuevos significados relacionados con contextos diferentes: un movimien- 
to característico de cuando se cumple el doble sentido en cualquier forma de signo, sea verbal sea no verbal. Pero también la función dramática del color requiere la separación, de la misma manera que la función dramática de la línea musical se debe a su autonomía con respecto a la de las imágenes.

La separación y la condición de un montaje «cromofónico». A propósito de lo cómico a color, Eisenstein critica a Disney el hecho de que el color se haya quedado en sus películas «musicalmente inorgánico», «nada más que un relleno: una coloración. El color no participa en la comicidad de la situación». Desarrollando la reflexión sobre la función de la separación en la realización cómica y dramática del color, en cuanto disuelve la natural y empírica convivencia del objeto con su color, Eisenstein llega a identificar la separación como momento necesario de toda creación artística y, es más, de toda acción creativa.

Se trata de una verdad ya presente en Platón, pero que es mucho más antigua y se puede encontrar en el mito bíblico de la creación del mundo (Dios separa la luz de las tinieblas, el agua de la tierra, la mujer del hombre) y en el principio del desdoblamiento del Tao chino en Ying e Yang. El principio de la división del Tao en Ying e Yang, parece ser, dice Eisenstein, el mismo de todo fundamental acto originario de la creación y de la conciencia creativa, entendidas, sobre todo como separación, sin la cual no es posible una unidad activa, orientada hacia un fin y planteada intencionalmente. La separación es creativa cuando, precisamente como en la del Tao en Ying e Yang, no comporta la autonomía de los elementos separados sino su interacción. La separación creativa requiere la mezcla, el intercambio de los elementos separados y, por lo tanto, requiere que los mismos estén inamoviblemente unidos a determinados papeles, que cada una de sus posiciones pueda invertirse, que se puedan cambiar de lugar entre ellas. La separación como principio de toda acción creativa es complementaria a la mezcla «carnavalesca» estudiada por Bajtín, y con la que se encuentra el mismo Eisenstein cuando estudia la estructura de la situación en la que se cambian de lugar los miembros de parejas como la del «príncipe / mendigo»: intercambio de posición social en los rituales, en los saturnales, intercambio de Ivan el Terrible y del príncipe tártaro Simeón Bekbulatovic, intercambio carnavalesco del tipo vida-muerte, masculino-femenino: un grupo de elementos que acomunan los trabajos de Eisenstein y de Bajtín (cf. Ivanov en Ivanov, Kristeva y otros, 1977: 99-100).

Polifonía dramatúrgica, separación y rotura de los nexos pasivos y realistas, unión de cosas que normalmente se mantienen separadas y diferenciadas: todo ello está conectado con el concepto eisensteiniano de ex-tasis. 
Ex-tasis, en el sentido literal de «salir fuera de sí», está indicando el modelo dinámico y temporal de las transformaciones y conmutaciones de un registro expresivo a otro (por ejemplo de la imagen a la música y de la música al color). Ex-tasis es el movimiento de la obra como conmutación de registros expresivos.

El cine tiene la posibilidad de realizar al máximo el proceso extático porque dispone de medios expresivos heterogéneos: encontramos de nuevo el concepto de la polifonía dramatúrgica de los medios de la acción cinematográfica. Con razón Pietro Montani (en la introducción a la trad. it. de Eisenstein, 1981) identifica una conexión entre el concepto eisenstiano de $e x$ tasis y el bajtiniano de «cuerpo grotesco». Desde un punto de vista ex-tático no existen separaciones y uniones definitivas, objetos monádicos, autosuficientes y estáticos: todas y cada una de las cosas se ven en devenir y unidas en un proceso generativo - como creadas y creadoras- de otras cosas. Análogamente, el cuerpo grotesco es un cuerpo en devenir, unido a otros cuerpos y al mundo. En la descripción bajtiniana del cuerpo grotesco encontramos expresiones, motivos de ejemplificación a los que Eisenstein recurre para describir el modelo ex-tático.

Para Bajtín, el «cuerpo grotesco» no está ni terminado ni definido, sino que se construye y se crea continuamente, y es el mismo, que construye y crea otro cuerpo. El papel más importante del «cuerpo grotesco» reside en esas partes y en esos lugares donde va más allá de sí mismo, sale de los límites preestablecidos, donde empieza la construcción de un nuevo (segundo) cuerpo: el vientre, el pene, la boca, el culo. Todas estas protuberancias y orificios se caracterizan por el hecho de que en ellos precisamente se traspasan los límites entre dos cuerpos, y entre el cuerpo y el mundo, y se producen los intercambios y las orientaciones recíprocas (cf. Bajtín, 1965). Eisenstein, para dar una imagen del ex-tasis en su «interpretación cómica» acude al dibujo de los canguros que salen unos del marsupio de otros: una cadena de canguros que salen unos de otros; o bien al dibujo que representa la mano con una pluma que está dibujando el perfil de un hombre, que está dibujando el perfil de un hombre, que está dibujando el perfil de un hombre, y así sucesivamente.

Si la cadena de los canguros que salen unos de otros ofrece una interpretación cómica de la fórmula del ex-tasis, su interpretación seria o patética nos la puede ofrecer, según Eisenstein, el cuadro de Leonardo da Vinci, «Santa Ana, la Virgen y el Niño», donde nos encontramos con un grupo de tres personas cada una de las cuales sale del vientre del precedente: «uno que está en 
otro que está en un tercero». En el plano puramente físico tenemos tres personajes - que representan tres generaciones- cada una de las cuales intenta huir de los brazos - del vientre - del más anciano, que queda, de esta forma, apartado. Así, el cuadro de Leonardo parece esconder una imagen extraordinariamente dinámica de la reproducción. Santa Ana que, en un crecimiento desenfrenado, se continúa en la Virgen y, más allá, en otra generación (cf. Eisenstein, 1981: 205).

Eisenstein concibe la dinámica estática como un proceso sin solución de continuidad, en la que algo genera algo que genera algo que genera algo. Un proceso análogo al del «discurso interno», del «monólogo interior» (del que Bajtín ha evidenciado la estructura dialógica), al cual Eisenstein dirige la atención sobre la base de los estudios psicolingüísticos de Vygotskij. El proceso continuo del pensamiento ha sido evidenciado también por Peirce, en base a su concepción del pensamiento como referencia de un signo a otro signo, «interpretantes» unos de otros, y que se subsiguen sin fin: una cadena ininterrumpida de signos, que se parecen a la serie de canguros del dibujo que Eisenstein cita. Como observa Charles S. Peirce, no existe intuición o conocimiento que no esté determinado por los conocimientos precedentes y por la ley de la asociación mental; la interrupción de una nueva experiencia no es nunca un hecho instantáneo, sino un evento que lleva tiempo y que pasa a través de un proceso continuo; por eso no existe ninguna excepción a la ley de que todo pensamiento-signo es traducido o interpretado por otro siguiente.

Eisenstein considera que las leyes de constitución del discurso interior son, precisamente, aquellas leyes que se encuentran en la base de toda variedad de leyes, que regulan la construcción de la forma y de la composición en la obra de arte (cf. Eisenstein, 1964: 108). Sobre todo el cine es el medio expresivo que puede realizar mejor el principio de la fluidez continua, que caracteriza el desarrollo del discurso interior, en la medida que el cine es el mayor representante moderno del arte de la dinámica ininterrumpida. Especialmente interesante, bajo este perfil, es la comparación que Eisenstein hace entre escritura y cine, sobre todo donde la posibilidad del cine de realizar el principio de la fluidez continua se compara con la escritura tal y como se lleva a cabo en determinados recursos literarios, especialmente en el «monólogo de Molly Bloom» del Ulises, de Joyce.

La escritura literaria, sobre todo de la novela, y la escritura del cine penetra en el laboratorio individual y social en el que las ideologías se forjan (cf. Bajtín, 1926-30; Bajtín y Voloshinov, 1927; Bajtín y Medvedev, 1928). Al contrario, las ideologías que ya están consolidadas resultarían un cuerpo 
extraño respecto al valor artístico y convierten el texto en un ensayo pedagógico, de panfleto, de discurso propagandístico, etc. La escritura artística de la novela y del cine ha tenido siempre que ver con ideologías dúctiles, inciertas, evasivas, híbridas, cuyos sujetos son, a su vez, indeterminados, divididos, plurales, privados de un rostro reconocible.

Por todas estas razones, bajo la superficie de la ideología dominante, que se identifica con la misma lógica del capital, y aparentemente exenta de contradicciones y oposiciones, la aproximación de la experimentación artística de la novela y del cine nos permite percibir las proyecciones ideológicas in nuсе. Hoy, la alteridad ideológica está sofocada por la identidad. La literatura, especialmente cuando se lee como lo hace Bajtín que detecta la génesis de la obra estética en el punto de vista del otro y en la exotopia, ofrece la posibilidad de escuchar un diálogo no formal, sino sustancial que subyace al difundido monologismo y a la ideo-lógica dominante de la productividad y de la comunicación funcional a esta fase del sistema del capitalismo.

\section{REFERENCIAS BIBLIOGRÁFICAS}

BAJTín, M. (1920-24). Hacia una filosofía del acto ético. De los borradores y otros escritos, prefacio y trad. del ruso de T. Bubnova, comentario de I. Zavala y A. Ponzio. Barcelona: Anthropos, 1997.

- (1952-53). «El problema de los géneros del discurso». En Bajtín (1979).

— (1959-60). «Il problema del testo». En Bajtín (1979).

- (1963). Problemas de la poética de Dostoievski, trad. del ruso de T. Bubnova. México: Fondo de Cultura Económica, 1986.

- (1965). La cultura popular en la Edad Media y en el Renacimiento. El contexto de François Rabelais, trad. del ruso de J. Forcat y C. Conroy (trad.). Madrid: Alianza, 1979.

— (1970-71). «Apuntes». En Bajtín (1979).

- (1975). Teoría y estética de la novela, trad. del ruso de H. S. Kriukova y V. Cazcarra (trad.). Madrid: Taurus, 1989.

- (1979). Estética de la creación verbal, trad. del ruso de T. Bubnova. México: Siglo XXI, 1982.

- (2003). Linguaggio e scrittura. 1926-30. Introd. de A. Ponzio, trad. de L. Ponzio. Roma: Meltemi. 
Bajtín, M. y Medvedev, P. (1928). El método formal en los estudios literarios, trad. del ruso de T. Bubnova. Madrid: Alianza, 1994; Il metodo formale e la scienza della letteratura, introd. de A. Ponzio. Bari: Dedalo, 1977.

Bajtín, M. y Voloshinov, M. V. (1927). Freud e il freudismo. Trad. del ruso de L. Ponzio. Introducción de A. Ponzio. Milano: Mimesis, 2005.

- (1929). El marxismo y la filosofía del lenguaje. Trad. del ruso de T. Bubnova. Madrid: Alianza, 1993; trad. it. Marxismo e filosofia del linguaggio, introd. de A. Ponzio. Lecce: Manni, 1999.

BARTHES, R. (1978). Leçons. París: Seuil.

- (1982). L'obvie et l'obtus. Essais critiques III. París: Seuil.

- (1984). Le bruissemente de la langue. París: Seuil.

BARTHES, R. y Havas, R. (1977). «Ascolto», Enciclopedia, 1. Turín: Einaudi.

Blanchot, M. (1955). L'éspace littéraire. París: Gallimard.

— (1969). L'Entretien infini. París: Gallimard.

- (1973). La folie du jour. Montpellier: Fata Morgana.

Calvino, I. (1988). Lezioni americane. Milán: Garzanti.

Deleuze, G. (1984). Cinema 1, Cinema 2. Milán: Ubulibri.

EISENSTEIN, S. M. (1961). Memorie. Roma: Editori Riuniti.

- (1963-1970). Izbrannye proizvedenija v sesti tomach. Moscú: Iskusstvo.

- (1964). Forma e tecnica del film e lezioni di regia. Turín: Einaudi.

— (1981). La natura non indiferente, P. Montani (ed.). Venecia: Marsilio.

- (1982). Il colore. P. Montani (ed.). Venecia: Marsilio.

Foucault, M. (1970). L'ordre du discours; trad. it. L'ordine del discorso. Turín: Einaudi, 1972.

Ivanov, I.; KRISTEVA, J. y otros (1977). Michail Bachtin. Teoria della letteratura, semiotica e marxismo, introd. de A. Ponzio. Bari: Dedalo.

JABÈs, E. (1982). Il libro della sovversione non sospetta, trad. de A. Prete. Milán: Feltrinelli, 1984. 
KierkegaArd, S. (1843). Diario di un seduttore. En Kierkgaard, EnterEller, vol III. Milán: Adelphi, 1978.

- (1995). Opere, C. Fabro (ed.). Casale Monferrato: Piemme.

Kristeva, J. (1977). Polilogue. París: Seuil.

KRYSINSKI, W. (2003). Il romanzo e la modernità, introd. de F. Muzzioli. Roma: Armando Editore.

LÉvinAS, E. (1961). Totalité et infini. La Haya: Nijoff.

- (1974). Autremente qu'être, on delà del' essence. La Haya: Nijoff.

- (1982). L'au-dela du verset. París: Minuit.

- (1999). Filosofia del linguaggio, a cura di J. Ponzio. Bari: Graphis.

- (2002) La libertà e il pensare all'altro, a cura di A. Ponzio, trad. di J. Ponzio. Roma: Meltemi.

Lotman, J. et al. (1979). Semiótica de la cultura, traducción de J. Lozano. Madrid: Cátedra.

Marcuse, (1968). L'uomo a una dimensione. Turín: Einaudi.

Medvedev, P. N.: vid. Bajtín, M. y Medvedev P. N. 1928.

- (1927). Il metodo formale nella scienza della letteratura, trad. del ruso de R. Bruzzese, introd. de A. Ponzio. Bari: Dedalo, 1977.

Morris, C. (1949). The Open Self. New York: Prentice-Hall, trad. italiana e introd. de S. Petrilli. Bari: Graphis.

Pasolini, P. P. (1990). «Il romanzo delle stragi». En Scritti corsari. Milán: Garzanti.

— (1972). Empirismo eretico. Milán: Garzanti, 1991.

— (1975). Scritti corsari. Milán: Garzanti, 1990.

— (1976). Lettere luterane. Turín: Einaudi, 1981.

— (1992). Petrolio. Turín: Einaudi.

Peirce, C. S. (1935-66). Collected Papers. Cambrige, Harvard: Harvard University Press.

Petrilli, S. (2005). Percorsi della semiotica. Bari: Graphis.

Petrilli, S. y Ponzio, A. (1998). Signs of Research on Signs, Semiotische Berichte, Österreichschen Gesellschaft für Semiotik, Jg. 22, 3/4. 
- (2000). Philosophy of Language, Art and Answerability in Mikhail Bakhtin. Toronto: Legas.

Petrilli, S. y Calefato, P. (eds.) (2003). Logica, dialogica, ideologica. Milán: Mimesis.

Petrus Hispanus (1230). Tractatus. Summule Logicales, trad. del latín de A. Ponzio. Milán: Bompiani.

Ponzio, A. (1974). Producción lingüística e ideología social. Madrid: Corazón Editor.

— (1990). Man as a Sign, S. Petrilli (ed.). Berlín: Mouton De Gruyter.

- (1992a). Production linguistique et idéologie sociale. Candiac (Québec): Les Éditions Balzac.

- (1992b). Tra semiotica e letteratura. Introduzione a M. Bachtin. Milán: Bompiani.

— (1993). Signs, Dialogue, and Ideology, S. Petrilli (ed.). Ámsterdam: John Benjamins.

- (1994). Scrittura, dialogo, alterità. Tra Bachtin e Lévinas. Florencia: La Nova Italia.

- (1995). El juego del comunicar. Entre literatura y filosofia, edición y trad. de M. Arriaga Flórez. Valencia: Episteme.

- (1996). Sujet et altérité in Emmanuel Levinas. París: L'Harmattan.

- (1998). La revolución bajtiniana. El pensamiento de Bajtín y la ideología contemporánea. Madrid: Cátedra.

- (2001). Enunciazione e testo letterario nell' insegnamento dell' italiano come LS. Perugia: Guerra.

- (2003a). I segni tra globalità e infinità. Per la critica della comunicazione globale. Bari: Cacucci.

- (2003b). Tra semiotica e letteratura. Introduzione a Michail Bachtin. Milán: Bompiani.

- (2004). Semiotica e dialettica. Bari: Edizioni dal Sud.

Ponzio, A. y Petrilli, S. (2000). Il sentire della comunicazione globale. Roma: Meltemi. 
- (2001). Sebeok and the Signs of Life. London: Icon Books.

- (2002). I segni e la vita. La semiotica globale di Thomas A. Sebeok. Milán: Spirali.

- (2003a). Semioetica. Roma: Meltemi.

- (2003b). View in Literary Semiotics. Toronto: Legas.

Ponzio, A.; Rossi-Landi, F. y SchafF, A. (1976). Lingüística y sociedad. Madrid: Siglo XXI.

ROMERa CASTILlo, J. et alii (1995). Bajtín y la literatura. Madrid: Visor Libros.

Rossi-Landi, F. (1968). Il linguaggio come lavoro e come mercato. Milán: Bompiani (Nueva ed. 2003; trad: El lenguaje como trabajo y como mercado. Caracas: Monte Ávila, 1972; A linguagen como trabalho e como mercado, A. Fornoni trad. São Paulo: Difel, 1985).

- (1972). Semiotica e ideologia. Milán: Bompiani (Nueva ed. 1994); trad. parcial: Semiótica y estética. Buenos Aires: Nueva Visión, 1976.

- (1977). Linguistics and Economics. La Haya: Mouton.

— (1982). Ideologia. Nueva ed. Milán: Meltemi, 2005.

- (1990). Criterios para el estudio ideológico de un autor, trad. de C. Baccin. La Plata.

- (1992). Between Signs and Non-sings, S. Petrilli (ed.). Ámsterdam: J. Benjamins.

Schaff, A. (1993). Humanismo ecuménico, prólogo de J. N. García-Nieto y J. Gómez Caffarena. Madrid: Trotta.

— (1993). Mi siglo XX. Madrid: Editorial Sistema.

- (1998). Meditaciones sobre el socialismo. México y Madrid: Siglo Veintiuno.

Schaff, A.; Latouche, S.; Rossi-Landi, F.; Ponzio, A. y Pierre-Henri, J. Lingüística, Sociedad e Política. Lisboa: Ediçôes 70.

Sebeok, T. (1991). A Sign Is Just a Sign. Bloomington-Indianapolis: University Press. 
TALENS, J. (1994). Escritura contra simulacro. El lugar de la literatura en la era electrónica. Utopías, vol. 56 de la colecci;on del Centro de Semiótica y Teoría del Espectáculo. Valencia: Episteme.

Talens, J. y Company, J. M. (1979). «El espacio textual: tesis sobre la noción de texto». Cuadernos de Filología 1, 35-48.

Talens, J.; Romera, J.; Tordera, A. y Hernández Esteve, V. (1990). Elementos para una semiótica del texto artístico. Madrid: Cátedra.

Voloshinov, V. N. Vid. Bajtín y Voloshinov, 1927 y 1929. 